\title{
A Contrastive Study of Grammar Translation Method and Communicative Approach in Teaching English Grammar
}

\author{
Shih-Chuan Chang \\ Department of Foreign Languages, Cheng Shiu University \\ Chengcing Rd. Niaosong Township, Kaohsiung County, 833, Taiwan \\ Tel: 886-07-731-0606-6212 E-mail: 1lc724@csu.edu.tw
}

Received: October 21, $2010 \quad$ Accepted: January 11, $2011 \quad$ doi:10.5539/elt.v4n2p13

\begin{abstract}
The Grammar Translation Method and the Communicative Approach have both played important roles in grammar teaching. Which is better, the Grammar Translation Method or the Communicative Approach? This paper aims to compare the controllability and feasibility of these two approaches and find out which one is more suitable for grammar teaching in Taiwan. Two classes were selected and taught by the Grammar Translation Method and the Communicative Approach respectively. The college admission test showed that they share a similar level of the overall English proficiency before the intervention. The pre-test demonstrated that there wasn't any distinction between the two classes in their grammatical competence. The post-test embodied that there was significant difference in their grammatical competence between the two classes. The scores of the students in the Experimental Class were higher than that in the Control Class. The result showed that grammar teaching in the framework of the Grammar Translation Method is better than the Communicative Approach. Nevertheless, the Communicative Approach emphasizes fluency and the Grammar Translation Method is concerned with accuracy. Fluency and accuracy are the target for English learning. So the best way to improve the situation is to combine both methods in teaching English Grammar.
\end{abstract}

Keywords: Grammar translation method, Communicative approach, Grammar teaching

\section{Introduction}

\subsection{The current situation of grammar teaching for English majors in colleges}

Curricula for English Majors require that grammar teaching should be arranged as part of the program. As one of the required courses, grammar has been taught to English majors in universities and colleges for years. It is known that "grammar is a set of rules that define how words (or parts of words) are combined or changed to form acceptable units of meaning within a language" (Penny, 2000). Guaranteeing the accuracy of the sentences mainly depends on the learner's mastery of grammar. Grammar, which is an indispensable part of a language, is so important that the teachers and students have always attached great importance to grammar teaching and learning. For the above-mentioned reasons, how to make grammar teaching and learning effective and efficient is an important task for both English teachers and researchers.

Although college English teaching and learning research in Taiwan has undergone great changes during the past decades. The current grammar teaching in colleges is still characterized by the adoption of the traditional teaching method, which is known as the Grammar Translation Method. With this model, language structures are presented by the teacher, then practiced in the form of spoken or written exercises, and then used by the learners in less controlled speaking or writing activities. Although the traditional grammar teaching method helps improve the students' mastery of the grammatical rules, the students cannot use these rules flexibly and appropriately in communication. That is to say, the traditional grammar teaching method has its disadvantages which prevent the students from developing their communicative competence. Firstly, the traditional grammar teaching method is teacher-centered. As a result, the majority of the classroom time is spent on the teachers' elaborate explanation of English grammar rules, while all the students are either listening or taking notes. Thus little attention is paid to the development of English communicative competence. The students accept the English knowledge passively in the procedures set ahead of time by English teachers step by step. There is little use of the English language. The typical exercise is to translate sentences from English into Taiwanese or vice versa, to fill in the blank with a proper word and to correct errors in a sentence. So the students lack English communicative opportunities. Secondly, memorization and rote learning are the basic learning techniques, which cannot help to arouse students' interest, build their self-confidence 
or improve their communicative strategies in English learning and even makes them fear English grammar learning. An alternative to the traditional grammar teaching method is the Communicative Approach. The Communicative Approach makes language teaching as in real-world situation. Grammar learning is emphasized by communication through the approaches of 'learning by doing', through students' participation or co-operative completion of teaching tasks between or among students and teachers, then grammar can be acquired naturally by learners.

\subsection{Significance of the research}

For decades, English grammar teaching in Taiwan has been greatly influenced by some traditional teaching methods, such as the Grammar Translation Method, the Direct Method, and the Audio-Lingual Method. The Communicative Language Teaching or Communicative Approach was introduced into Taiwan in the late 1970s. Fostering the communicative competence is its central goal. Communicative competence is concerned not only with what is grammatical but what is appropriate in a given social situation. Hymes (1972) proposes that language should be taught in communicative situations in order for learners to achieve communicative competence. Learners should not only be equipped with language knowledge, but also be capable of appropriately using the foreign language in various situations. However, it has been gradually assumed among the scholars and teachers in Taiwan that communicative competence makes the ultimate objective of English Language teaching, and the Communicative Approach, if completely and well conceived, does not involve the rejection of grammar. On the contrary, it involves recognition of its central mediating role in the use and learning of language (Widdowson, 1978). What English language teaching in Taiwan counts is to make a good negotiation between the traditional and modern teaching method; to make a proper conception of communicative competence and develop a flexible communicative way to formal instruction in the classroom. What is called grammatical competence has been regarded as a significant component of learner's communicative competence by many linguists (Stern, 1992; Richards, 2004). In addition, the ups-and-downs of ELT in Taiwan in recent decades has given us reflection on it. Many Taiwanese scholars and experts have discussed and confirmed the possibilities of the combination of the Grammar Translation Method and the Communicative Approach and there is a growing comeback of the role of grammatical instruction in the classroom. Based on the notion of communicative competence and the significant role of grammar teaching, this paper aim to find out which one (Communicative Approach and Grammar Translation Method) is more suitable for grammar teaching in College education in Taiwan.

\section{Literature review}

\subsection{Grammar teaching}

\subsubsection{Definition of grammar}

In the Oxford Advanced Learner's Dictionary of Current English with Taiwanese Translation, grammar is referred to as "study or science of, rules for, the words into sentences (syntax), and the forms of words (morphology)". The Longman Dictionary of Contemporary English defines grammar as "the study of use of the rules by which words change their forms and are combined into sentences." In fact, grammar is "multi-dimensional" (Batstone, 1994) and has multi-meanings. It is generally thought to be a set of rules for choosing words and putting words together to make sense. Every language has grammar. It has been held that if a language is a building, the words are bricks and the grammar is the architect's plan. One may have a million bricks, but do not make a building without a plan. Similarly, if a person knows a million English words, but he doesn't know how to put them together, then he cannot speak English (Brumfit, 2000). In other words, grammar is a framework to describe languages.

\subsubsection{Principles of grammar teaching}

Looking at what principles can guide us in the teaching of grammar. Both Hedge and Thornbury (2001) give us some worthy answers. Hedge (2000) considers that the presentation of grammar to learners should facilitate learning in many ways: It can provide input for noticing output and accurate forms of English; it can present high-frequency grammatical items explicitly to speed up learning; it can provide information about the communicative use of language structures by contextualizing them in spoken and written form; it can give information implicitly through exposure to examples or explicitly through instruction on the stylistic variation of language form. Thornbury (2001) summarizes some rules of thumb about the teaching of grammar: (1) the Rule of Context-teaching grammar in context, i.e. teaching grammatical forms in association with meanings (The choice of one grammatical form over another is always determined by the meaning the speaker or writer wishes to convey); (2) the Rule of Use - teaching grammar in order to facilitate the learners' comprehension and production of real language, rather than as an end in itself; (3) the Rule of Economy - to fulfill the rule of use, be economical (economizing on presentation time in order to provide maximum practice time); (4) the Rule of Relevance-teach only the grammar that students have problems with (starting off by finding out what students already know, and don't assume that the grammar of English is a wholly different system from the learners' mother tongue); (5) the Rule of Nurture-teaching doesn't necessarily 
cause learning - not in any direction (rather than occurring as flashes of insight, language learning is more often than not a process of gradual approximation. Instead of teaching grammar, try to provide the right conditions for grammar learning); (6) the Rule of Appropriacy - interpret all the above rules according to the levels, needs, interests, expectations and learning styles of the students (Giving a lot of prominence to grammar, or it may mean actually teaching grammar at all - in any up-front way). Ellis defines the definition of grammar teaching from a broad sense: Grammar teaching involves any instructional technique that draws learners' attention to some specific grammatical form in such a way that it helps them either to understand it metalinguistically and/or process it in comprehension and/or production so that they can internalize it (Ellis, 2006).

\subsection{A brief survey of Grammar Translation Method}

\subsubsection{The history of Grammar Translation Method}

In the Western world, "foreign" language learning in schools was synonymous with the learning of Latin or Greek. Latin, thought to promote intellectuality through "mental gymnastics", was only until relatively recently held to be indispensable to an adequate higher education. Latin was taught by means of what has been called the Classical Method: focus on grammatical rules, memorization of vocabulary and of various declensions and conjugations translation of texts, doing written exercises. (Brown, H.D., 1994)

As other languages began to be taught in educational institutions in the eighteenth and nineteenth centuries, the Classical Method was adopted as the chief means for teaching foreign languages. Little thought was given to teaching oral use of languages. After all, languages were not being taught primarily to learn oral/aural communication but to learn for the sake of being "scholarly" or, in some instances, for gaining a reading proficiency in a foreign language. Since there was little if any theoretical research on second language acquisition in general, or on the acquisition of reading proficiency, foreign languages were taught as any other skill was taught.

In the nineteenth century, the Classical Method came to be known as the Grammar Translation Method. Grammar-Translation Method began in Germany, or more accurately, Prussia, at the end of the eighteenth century and established an almost impregnable position as the favored methodology of the Prussia Gymnasien after their expansion in the early years of the nineteenth century. The origins of the method do not lie in an attempt to teach languages by grammar and translation, these were taken for granted anyway. The original motivation was reformist, the traditional scholastic approach among individual learners in the eighteenth century had been to acquire learners a reading knowledge of foreign languages by studying a grammar and applying this knowledge to the interpretation of texts with the use of a dictionary. Most of them were highly educated men and women who were trained in classical grammar and knew how to apply the familiar categories to new languages. However scholastic methods of this kind were not well suited to the capabilities of younger school pupils and, moreover, they were self-study methods which were inappropriate for group teaching in the classroom.

The Grammar-Translation Method was an attempt to adapt these traditions to the circumstances and requirements of schools. Its principal aim was to make language learning easier. The central feature was the replacement of traditional texts by exemplary sentences. Grammar-Translation was the offspring of German scholarship, the object of which, according to one of its less charitable critics, was "to know everything about something rather than the thing itself" (W H.D Rouse, quoted in Kelly 1969).

\subsubsection{Previous Related Researches into Grammar Translation Method}

The related researches are as follows:

(1) Stern, H. H. (1992) in his book "Issues and Options in Language Teaching" indicates "a contrastive analysis, just as the comparative linguistics studies, is indeed very important for the second language learner. Therefore translation in one form or another can play a certain part in language learning".

(2) Brown H.D. (1994), in his Principles of Language Learning and Teaching, states "It does virtually nothing to enhance a student's communicative ability in the language."

(3) Cunningham, C. (2000) in the paper "Translation in the Classroom- a Useful Tool for Second Language Acquisition" indicates "while there may indeed be some negative effects from using translation, there is a place in the learning environment for translation. Translation can contribute to the students' acquisition of the target language, at all levels".

(4) Austin J Damiani (2003) in his paper "The Grammar Translation Method of Language Teaching” states "As a teacher, I liked using the grammar translation method because I could assume the intelligence of my students; I could talk to them like the intelligent people that they are, and we could talk about the grammar and vocabulary that I was teaching. In another method, I would have had to use simple language and familiar phrases to communicate in 
the target language, and even then, I could not be sure that my students knew and understood what it was that they were saying."

\subsection{The positive views on the Grammar Translation Method}

Duff, unlike the behaviorists, has a positive view of the role of the learner's mother tongue in second language acquisition. He says that our first language forms our way of thinking and, to some extent, shapes our use of the foreign language (choice of words, word order, sentence structure, etc.). Translation helps us understand the influence of one language on the other, e.g., areas of potential errors caused by negative transfer from the first language. Fully aware of the interference, students will try to avoid making such errors when performing in the second language. When errors do occur, the students will be able to explain why and try not to make the same mistakes again.

Chellapan (1982) in his paper "Translanguage, Translation and Second Language Acquisition", points out: "Translation can make the student come to closer grips with the target language. A simultaneous awareness of two media could actually make the student see the points of convergence and divergence more clearly and also refine the tools of perception and analysis resulting in divergent thinking."

A contrastive analysis, as in the comparative linguistics studies, "is indeed very important for the second language learner. Therefore, translation in one form or another can play a certain part in language learning" (Stern, 1991). By adopting a contrastive study approach, similar to the interlineal translation employed in comparative linguistics, pedagogical translation would not only help reveal the structural features of L2 by means of L1 and expose the similarities and differences on various linguistic levels between the two languages to the learner, but by representing these structures of L2 in way to adapt to the norms of L1, produces a readable TT (Target Text) for the learner's easy reference.

\subsection{Communicative Approach (CA)}

In contrast to the Grammar Translation Method is the "revolutionary" Communicative Approach, which shifts attention from language competence to communicative competence. Communicative Language Teaching (CLT) originated from Europe, with the increasing interdependence of European countries in the 1960s. CLT spread into Taiwan in the late 1970s, and has been applied in both advanced and fundamental education up to the present. Both American and British proponents now see it as an approach that aims to (a) make communicative competence as the goal of language teaching and (b) develop procedures for the teaching of the four language skills. "The Communicative Language Teaching stresses the importance of providing learners with opportunities to use English for communicative purposes and attempts to integrate such activities into a wider program of language teaching" (Howatt, 1984). According to this approach, teaching and learning are for communication. It presupposes that language always occurs in a social context, and it should not be divorced from its context when it is being taught. Learning in order to communicate is now commonplace.

\subsubsection{The background of Communicative Approach}

In 1971 a group of experts began to investigate the possibility of developing language courses on a unit-credit system, a system in which learning tasks are broken down into "portions or units, each of which corresponds to a component of a learner's needs and is systematically related to all the other portions" (Va Ek \& Alexander, 1980). The group used studies of the needs of European language learners, and in particular a preliminary document prepared by a British linguist, Wilkins (1972), which proposed a functional or communicative definition of language that could serve as a basis for developing communicative syllabuses for language teaching. Wilkins's contribution was an analysis of the communicative meanings that a language learner needs to understand and express. Rather than describe the core of language through traditional concepts of grammar and vocabulary, Wilkins attempted to demonstrate the systems of meanings that lay behind the communicative uses of language. He described two types of meanings: notional categories (concepts such as time, sequence, quantity, location, frequency) and categories of communicative function (requests, denials, offers, complaints). Wilkins later reviewed and expanded his document into a book called Notional Syllabuses (Wilkins, 1976), which had a significant impact on the development of the Communicative Approach. The Council of Europe incorporated his semantic/communicative analysis into a set of specifications for a first-level communicative language syllabus. The threshold level specifications (Va Ek \& Alexander, 1980) have had a strong influence on the design of communicative language programs and textbooks in Europe. The work of the Council of Europe; the writings of Wilkins (1976), Widdowson (1999), Brumfit (2000), Keith Johnson (1999), and other British applied linguists on the theoretical basis for a communicative or functional approach to language teaching; the rapid application of these ideas by textbook writers; and the equally rapid acceptance of these new principles by British language teaching specialists, curriculum development centers, and even governments gave prominence nationally and internationally to what came to be referred to as the 
Communicative Approach. Although the movement began as a largely British innovation, since the mid-1970s the scope of CA has expanded widely.

\subsubsection{Reasons for the Communicative Approach not suitable for Taiwanese college students}

\subsubsection{The negative views on the Communicative Approach}

Widdowson (1999) says that "learners do not very readily infer knowledge of the language system from their communicative activities." “Communicative Language Teaching (CLT) values, among other things, learner-centeredness, which is, giving the learners more responsibility and involvement in the learning process. This is often achieved through discovery learning activities and through group work as opposed to the traditional teacher-fronted lesson. CLT also takes a relatively relaxed attitude towards accuracy in the belief that meaning takes precedence over form. Finally, CLT has inherited the humanist view that language is an expression of personal meaning, rather than an expression of a common culture. Such notions, it is argued, derive from very Western beliefs about education and language. Its critics argue that CLT is an inappropriate methodology in those cultural contexts where the teacher is regarded as a fount of wisdom, and where accuracy is valued more highly than fluency" (Thornbury, S., 2003).

The Communicative Approach has come under attack from teachers for being prejudiced in favor of native-speaker teachers by demanding a relatively uncontrolled range of language use on the part of the student, and thus expecting the teacher to be able to respond to any and every language problem which may come up. In promoting a methodology which is based around group and pair work, with teacher intervention kept to a minimum during, say, a role-play, the Communicative Approach may also offend against educational traditions which it aimed to supplant. The Communicative Approach has sometimes been seen as having eroded the explicit teaching of grammar with a consequent loss among students in accuracy in the pursuit of fluency" (Harmer J., 2003).

According to Ma Yinchu and Huang Jinyan (1992), its other demerits also deserve our attention:

(1) It makes greater demands upon the professional training and skill of the teachers. The teacher has to know when to take part and when to stand aside. In terms of preparation and professional skill in knowing when and how to guide or leave the students alone, it demands very much more energy and adaptability from the teacher. The teacher also needs to be more confident in using the foreign language.

(2) It does not offer the teacher the security of the textbook. Whereas, with more traditional approaches, it is enough for the teacher to follow the textbook, here it is necessary for him to select, adapt and invent the materials he uses.

(3) Because it appears to go against traditional practice, it often meets with opposition, especially from older teachers and learners (Ma Yinchu \& Huang Jinyan, 1992).

Also, according to Xu Yingcai (1991), language is like an ocean consisting of, so to speak, so many syntactic and lexical details as well as so many functional and notional possibilities that obviously no second language learner is able to cover them all in his or her study. This is especially true of the students trained under the Communicative Approach, since they are bound to sentences' particular functions. Thus, they are sometimes unavoidably required to express what they have never come across in their study. In this case, they are forced to create something of their own. As they lack the knowledge of grammar, they are likely to make grammatically incorrect sentences. Therefore, the Communicative Approach encourages some grammatical inaccuracy.

In addition to the above-mentioned disadvantages, direct correction of speech errors is usually avoided if they do not seriously affect the communicative purposes. This kind of practice may lead to fossilization of learner's errors.

\subsubsection{The Reasons for the Communicative Approach is not accepted by Taiwanese college students}

Nevertheless, the application of the communicative language approach in Asia countries hasn't provided expected results. Burnaby and Sun's study (1989) claimed that teachers in China found it difficult to use communicative language approach because of the class sizes, resources and equipment. Sano et al. (1984) point out that the participants in the study did not feel a pressing need to use English, so that the goal of communicative competence seemed too distant for them. Ellis (1994), who studied communicative language approach in Vietnam, also confirmed that the class size, grammar-based examinations, and lack of exposure to authentic language as constraints on using communicative language approach.

There are three reasons why communicative approach is not accepted by Asian students.

(1) According to Larson-Freeman (1986), the most obvious characteristics of CLT is that everything that is done with a communicative approach. In CLT, There is supposed to be a variety of activities which provide students opportunities to practice communicating meaningfully in different contexts. Nevertheless, students in Taiwan intend to associate games and similar activities with entertainment and are skeptical of their use as learning tools. Students, 
who have learned English in a teacher-centered approach, have been used to attending classes on reading and grammar structures. It is not unusual to have questions like "Could you explain the sentence for me, Could you translation this sentence into Chinese?", "Why is the past perfect tense used here?" Students are eager to understand every word in the context and special grammar structure. As a result, most of the time is spent on the teacher's elaborate explanation of language points and little attention is paid to the training of students' communicative competence.

(2) Communicative competence is essential for those who want to study in an English-speaking country. Lu (2004), a high school teacher who applied the communicative approach in his class, points out that the communicative approach cannot be used in China because living in China and hearing and speaking Chinese all day, thinking in English is impossible as few people have opportunities to interact with foreigners. The situation is same here in Taiwan; most of the students do not need to use English except in the English class and most of the students in universities have never had a chance to visit any English-speaking countries so that they have little knowledge about English let alone the culture of English-speaking countries. If the teacher insists on asking the students to discuss or speak out without letting them understand the cultural aspects of the language they are supposed to use, it is unlikely for students to communicate freely in class.

(3) The communicative approach might have been proved to be the best way of training students in ESL learners. However, it doesn't meet the needs of learners in distant lands, who learn English for a different purpose and who have no hope of ever visiting the target country and no desire to adopt the target culture.

\section{Methodology}

\subsection{Purpose of the Experiment}

The following are concrete descriptions of all the purpose for the experiment:

The first research aims to discover whether learners in the experimental class can make a significant progress in grammar learning after experiencing an experimental semester. The second research is designed for the purpose of seeing through the experimental semester whether learners in the experimental class can make more progress in grammar learning than those in the control class. The third research aims to find out whether the Grammar Translation Method is more effective in improving learners' learning confidence, and motivation than the Communicative Approach?

\subsection{Subjects}

In the experiment, two classes were selected from Applied Foreign Language Department as the Experimental Class and Control Class. The achievement of the college admission test showed that they share a similar level of the overall English proficiency. The two classes were taught by the Grammar Translation Method and the Communicative Approach respectively, and they both have grammar lessons three times a week.

\subsection{Instruments and the Design}

(1) Pre-test: Pre-test is used to test the subjects' grammatical competence before the experiment. The testing paper for the pre-test includes 50 multiple choices with a full mark of 100. If the student gets one of them correct, he/she will get 2 marks. Otherwise, he/she will get 0 . The contents of the testing paper include the following grammatical items: No.1-10 are to test the subjects' imperatives; No.11-20 are to test the subjects' passive voice; No.21-30 are to test the subjects' attributive clause; No.31-40 are to test the subjects' non-finite verbs; No.41-50 are to test the subjects' subjunctive mood.

(2) Post-test: Post-test is used to test the subjects' grammatical competence after the experiment. The testing paper for the post-test includes 50 multiple choices with a full mark of 100. If the student gets one of them correct, he/she will get 2 marks. Otherwise, he/she will get 0 . The contents of the testing paper include the following grammatical items: No.1-10 are to test the subjects' imperatives; No.11-20 are to test the subjects' passive voice; No.21-30 are to test the subjects' attributive clause; No.31-40 are to test the subjects' non-finite verbs; No.41-50 are to test the subjects' subjunctive mood.

(3) Questionnaire: The questionnaire used after the teaching experiment is to explore students' attitude and reaction to the teaching approach they receive during the year. It includes some multiple-choice questions. The questions are about the students' opinions about grammar learning and teaching, their English grammar learning interest, motivation and confidence after the experiment. Before students answer the questions in the questionnaires written in English, the teacher and author will explain the questions carefully to guarantee that the students have a thorough understanding of the questions and the results will reflect the thought of students truthfully. The questionnaires will be completed by all the subjects, 42 from experimental group and 44 from control group. After the completion of the 
questionnaires, the data will be collected and analyzed.

\subsection{Procedures}

In the first semester of 2008 to 2009 academic year, the experiment was carried out. The experiment was divided into three stages and finished in four months. (See Table 3-1)

At the first stage (Week 1), an examination paper was distributed to all the participants. The main task of this stage is to compare and analyze the pre-test scores of the two classes so that we can make sure the two classes are in the same ground. Also, from the test result we can know their condition about grammatical competence. The time allotted for examination is fifty minutes.

The second stage (Week 2-17) is the experimental time. The Imperatives, Passive Voice, Attributive Clause, Non-finite Verbs, and Subjunctive Mood were taught during this period. All the participants used the same teaching materials and were taught four lessons each week. Each lesson had fifty minutes. The author taught the two classes using two different methods: the Experimental Class adopted the Grammar Translation Method, while the Control Class adopted the Communicative Approach in grammar teaching.

The third stage (week 18), a post-test was conducted to all participants. Scores of the two classes of students were collected then to test the effectiveness of the learner development program on their grammar performance. Analysis of data was done with SPSS 16.0.

\subsection{Data Collection}

All the tests are implemented under the supervision of the English teachers of the experimental class and the researcher. The tests are respectively taken at the beginning and at the end of the semester. Scores are seriously given based on the scoring criteria in each part. The researcher makes analysis on experimental group scores by using SPSS 16.0. Independent Samples T-test and Paired Samples Test will be taken to see whether the subjects can make a significant progress in grammar competence through the Grammar Translation Method. Grammar scores are adopted and the confidence interval is set at $95 \%$.

\subsection{Results and Analysis}

After all the raw data were collected, the statistical analyses were made with the help of SPSS to check if the two teaching methods had significantly different effects on developing grammatical competence. The results of the statistical analyses will be presented in relation to the research questions:

(1) Whether learners in the Experimental Class can make a significant progress in grammar learning after experiencing an experimental semester;

(2) Whether learners in the Experimental Class can make more progress in grammar learning than those in the Control Class through the experimental semester.

(3) Whether the Grammar Translation Method is more effective in improving learners' learning confidence and motivation than the Communicative Approach?

Results of Statistical analysis of the scores of the pre-test and post-test of the two groups can help us to answer the first two questions. Analysis of the responses to the questionnaires can help us answer the second question.

\subsubsection{Date analysis of the subjects' grammatical competence before the experiment}

The pre-test was carried out in order to show the same English level of the two classes. It included 50 multiple choices, which were composed of five grammatical items-Imperatives, Passive Voice, Attributive Clause, Non-finite Verbs and Subjunctive Mood. Table 3.2 is the results from the pre-test scores between the two classes.

Table 3-2 indicates that the average score of the EC is a little lower than that of the $\mathrm{CC}$, but it does not show any significant differences between the two classes. For $Z=0.083, Z<1.96$. That is to say, the current grammar level of each class won't influence the effect of this experiment.

\subsubsection{Date analysis of the subjects' grammatical competence after the experiment}

The post-test is used to observe the changes between EC and CC after the experiment. The post-test paper was designed all the same as the pre-test paper in the format, the quantity of questions tested and the time allocation so as to guarantee the tests reliable, objective and comparable. Table 3.3 is the results from the post-test scores between the two classes.

Table 3-3 indicates that both classes made progress in English learning after the experiment. The average score of the EC is 79.67 and average score of the $\mathrm{CC}$ is 71.14 . The average score of the EC is much higher than that of the CC. It shows the significant differences between two classes. For $Z=4.2>1.96$. On the other hand, the table shows us that standard deviation is 7.31 in the EC, meanwhile, 11.23 in the CC. The gap between these two classes is too big: 
the deviation degree in the $\mathrm{CC}$ is much bigger than that in the EC. It shows that the Communicative Approach only fits small number of the students. Next, let's see the comparison of the two classes between the pre-test and the post-test respectively.

3.6.3 Date analysis of the experimental class's grammatical competence before \& after the experiment

Let us compare the standard deviations between the pre-test and the post-test in Table 3-4. It is easy to find that the standard deviation in the pre-test is nearly the same as that in the post-test. Furthermore, the average score after the experiment is much higher than that before the experiment. It indicates that a large number of students are attracted by the Grammar Translation Method. On the other hand, $Z=9.44>1.96$. It is illustrated by the data that teaching grammar through the Grammar Translation Method is much more effective than through the Communicative Approach, and the students' interests can lead to a much better effect.

\subsubsection{Date analysis of the control class's grammatical competence before \& after the experiment}

To our surprise, in Table 3-5, standard deviation is 6.74 before the experiment and is 11.23 after the four-month experiment. It shows that some students got a good mark, at the same time, some students' marks were lower than that before the experiment. The data, once more, indicates that the Communicative Approach only makes students improve on a small scale. On the contrary, the Grammar translation Method achieves better results in English grammar teaching.

\subsubsection{Date analysis of the result of questionnaire}

3.6.5.1 Date analysis of the item 1: It is important to teach grammar for English majors in colleges.

The item 1 is about the students' attitudes towards the importance of the grammar teaching. From table 3-6, it is clear that the majority of the experimental class and the control class think that it is important to teach grammar for English majors in colleges.

3.6.5.2 Date analysis of the item 2: The grammar teaching method conducted in our class helps me a lot in learning grammar.

Item 2 is about the students' attitudes towards the grammar teaching method conducted in their class. From table 3-7, 85.7 percent of the students in experimental group think the Grammar Translation Method is helpful to learn grammar, while in the control group only 77.3 percent of the students agree with Communicative Approach. The responses to item 3 indicate that the Grammar Translation Method is more helpful for students to learn grammatical rules.

3.6.5.3 Date analysis of the item 3: I'm confident that I can learn grammar well.

The item 3 is about the students' confidence in grammar learning. From table 3-8, it can be seen that 78.6 percent of the students in the experimental group are confident that they can learn grammar well, compared with 68.1 percent in the control group have confidence in their grammar learning. The result clearly shows that the Grammar Translation Method contributes a lot to the improvement of students' confidence in grammar learning.

3.6.5.4 Date analysis of the item 4: Much progress in English grammar learning has been made after one semester' learning.

Item 4 is about the results of one semester's grammar learning. From table 3-9, we can see 85.7 percent of the students in the experimental group think they have made progress in grammar learning. Not only does the progress refer to the mastery of grammatical rules, but also it refers to the improvement in students' confidence in grammar learning and enthusiasm for grammar learning. Compared with only 63.7 percent in the control group who are taught by the Communicative Approach, the result shows that the Grammar Translation Method is more effective in improving students' confidence and enthusiasm in grammar learning than the Communicative Approach.

3.6.5.5 Date analysis of the item 5: Method of teaching grammar in our class is acceptable.

Item 5 is about the acceptability of the different teaching methods which are employed in the experimental group and the control group respectively. From table 3-10, we can find that the majority of the students (88.1 percent) in the experimental group think that the Grammar Translation Method is acceptable in learning English grammar. In the control group, only 61.3 percent of the students accept the Communicative Approach, and 38.7 percent don't regard it as ideal. So a conclusion can be made that Grammar Translation Method is more popular with the students than the Communicative Approach. Based on the analyses of the results of the questionnaire, a conclusion can be drawn that the Grammar Translation Method is more effective in improving learners' learning confidence and motivation than the Communicative Approach.

\subsection{Summary}

To sum up, the Grammar Translation Method is a suitable approach for teaching grammar to college students. The 
students in the experimental class became more interested in grammar lessons. The result of the experiment also indicates that the Grammar Translation Method is a suitable teaching approach that can meet students' needs. On the contrary, the Communicative Approach is no longer suitable for the current English teaching situation due to its inefficiency and ineffectiveness. The results of this experiment can show that the marks of the experimental class are higher than that of the control class.

\section{Discussions and Conclusion}

\subsection{Findings}

From the above results, the major findings of the study can be summarized as follows:

(1) Firstly, learners in the experimental class made a significant progress in grammar learning after experiencing an experimental semester;

(2) After the experimental semester, learners in the experimental class made more progress in grammar learning than those in the control class;

(3) The Grammar Translation Method is more effective in improving learners' learning confidence, and motivation than the Communicative Approach.

\subsection{Limitations of the research}

Although the research has been carefully designed and implemented, and it has provided us with the expectant result, there are still some inevitable limitations in the study:

Firstly, the sample of the subjects is not large enough. Subjects in the present study are only sophomores of English majors. Therefore, the results of the present study might not be applicable to students of different proficiency levels.

Secondly, the duration of the experiment is not long enough. It is no surety that the same results will still be obtained in a long-time study.

Thirdly, the test papers used in this experiment are chosen and corrected by the author, so there must be some subjective factors which may influence the results of the experiment to a certain extent.

\subsection{Conclusion}

Without grammar, words hang together without any real meaning or sense. In order to be able to speak a language to some degree of proficiency and to be able to say what people really want to say, some grammatical knowledge must be grasped. By teaching grammar the teachers not only give the students the means to express themselves, but also fulfill their expectations of what learning a foreign language involves. There are no miracles on the way to learn a language. No matter how students are taught grammatical concepts, syntactic constructions and stylistic devices, or language conventions and editing concepts, they will not automatically make use of these in their talking. What this thesis intends to focus on is how to improve college students' grammatical competence and linguistic competence through the Grammar Translation Method.

Based on the theory of the Grammar Translation Method, this thesis compares the Grammar Translation Method and the Communicative Approach. In order to prove the effect of the Grammar Translation Method, the author of the thesis makes an experiment on her own classes. After one semester's teaching practice, the Grammar Translation Method is proved to be a suitable and successful teaching approach at Applied Foreign Language Department.

Firstly, the learners in the experimental class made a significant progress in grammar learning after experiencing an experimental semester.

Secondly, learners with the Grammar Translation Method in the experimental class made more progress in grammar learning than those who used the Communicative Approach in the control class.

Thirdly, the students' confidence in learning English was improved. Even those who lacked confidence in English in the past have become very active in the classroom activities.

Be in the view of college students' actuality in Taiwan, the best way to improve the situation is to combine both the Communicative Approach and the Grammar Translation Method in teaching English Grammar. That is because the Communicative Approach emphasizes fluency and the Grammar Translation Method is concerned with accuracy, fluency and accuracy are the target for English learning.

\section{References}

Austin J Damiani. (2003). The Grammar Translation Method of Language Teaching: London: Longman.

Batstone, R. (1994). Grammar, Oxford: Oxford University Press.

Brown, H. D. (1994). Principles of Language Learning and Teaching. Englewood Cliffs, NJ: Prentice Hall Regents. 
Brumfit, C. J. \& K. Johnson. (2000). The Communicative Approach to Language Teaching. Shanghai: Shanghai Foreign Language Education Press.

Burnby, B., \& Sun, Y. (1989). Chinese teachers' views of Western language teaching: Context informs paradigm. TESOL Quarterly, 23, 219-238.

Celce-Murcia. (1997). Direct approaches in L2 instruction: A turning point in communicative language teaching? TESOL Quarterly, 31: 141-152.

Chellapan, K.(1982). Translanguage, Translation and Second Language Acquisition. In F Eppert (Ed.), Papers on translation: Aspects, Concepts, Implications (pp. 57-63) Singapore: SEMEO Regional Language Center.

Chomsky, N. (1965). Aspects of the theory of syntax. Cambridge. MA.

Cunningham, C. (2000). Translation in the classroom-: A useful tool for second language Acquisition. http://www.cels.bham.ac.uk/resources/essay/cindyc2.pdf

Ellis, R. (1994). The Study of Second Language Acquisition. Oxford: Oxford University Press.

Ellis, R. (2006). Current issues in the teaching of grammar: an SLA perspective. TESOL Quarterly, 40 (1): 83-107.

Harmer Jeremy. (2003). How to teach English. Beijing: Foreign Language Teaching and Research Press.

Hedge, T. (2000). Teaching and Learning in the Language Classroom. Oxford: Oxford University Press.

Howatt, A. P. R. (1984). A History of English Language Teaching. Oxford: Oxford University Press.

Keith Johnson. (1999). Encyclopedic dictionary of applied linguistics: A handbook for language teaching. Oxford: Wiley-Blackwell Press.

Kelly, L.G. (1969). 25 Centuries of Language Teaching. Newbury House Publishers..Rowley, MA.

Larson-Freeman, Diana. (1986). Techniques and principles in Language teaching. Oxford: OUP.

Ma Yinchu \& Huang Jinyan. (1992). A Practical Guide to English Teaching Methodology. Changsha: Hunan Normal University Press.

Musumeci, D. (1997). Breaking the tradition: An exploration of the historical relationship between theory and practice in second language teaching. N.Y.: McGraw-Hill.

Oller, Obrecht. (1968). Pattern Drill and Communicative Activity: A Psycholingistic Experiment. International Review of Applied Linguistics 6, 165-174.

Penny, R. (2000). Variation and change in Spanish. Cambridge: Cambridge University Press.

Raymond Murphy. (2000). Grammar in use: self-study reference and practice for students of English. Cambridge: Cambridge University Press.

Richards, J . et al. (2004). Approaches and Methods in Language Teaching. Cambridge: Cambridge University Press.

Rivers, W. M. and Temperly, M. S. (1978). A Practical Guide to the Teaching of English as a Second Language. Oxford: Oxford University Press.

Sano, M., M. Takahashi and A. Yoneyama. (1984). Communicative language teaching and local needs. ELT Journal 38(3): 170-177.

Smith, M. (1980): Consciousness raising and the second language learner. In: Applied Linguistics 2, 159-168.

Spada, N., \& Lightbown, P. (1999). Instruction, first language influence, and developmental readiness in second language acquisition. The Modern Language Journal, 83: 1-22.

Stern, H. H. 1991. Fundamental Concepts of Language Teaching. Oxford: Oxford University Press.

Stern, H . H. (1992). Issues and options in language teaching (edited posthumously by Patrick Allen \& Birgit Harley). Oxford: Oxford University Press.

Thornbury, S. (2001). Uncovering grammar. Oxford: McMillan Heinemann.

Thornbury, S. (2003). How to Teach Grammar. Beijing: World Affairs Press.

Tomlin, R.S. (1997). Functional grammars, pedagogical grammars, and communicative language teaching [in:] T. Odlin (ed.) Perspectives on Pedagogical Grammar. Cambridge: Cambridge University Press.

Va Ek, J., Alexander L. (1980). Threshold level English. Oxford: Pergamon. 
Widdowson, H. (1978). Teaching language as communication. Oxford: Oxford University Press.

Widdowson, H. (1999). Aspects of Language Teaching. Shanghai: Shanghai Foreign Language Education Press.

Wilkins, D. A. (1972). Linguistics in Language Teaching. Oxford: Arnold

Wilkins, D. A. (1976). Notional Syllabuses. London: Oxford University Press.

Xiaohui, (2004). Grammar Translation and Teaching Research. Shanghai: Fudan university press.

$\mathrm{Xu}$ Yingcai. (1991). A Comparison between the Audiolingual Approach and the Communicative Approach in Second-Language Teaching. In Li Yinhua. ed. Fudan workpapers on the Teaching of English to Non-majors. Shanghai: Shanghai Foreign Language Education Press.

Table 3-1. Procedures Involved in the Experiment

\begin{tabular}{|l|l|l|l|}
\hline Week & Procedures & Week & Procedures \\
\hline Week 1 & pre-test & Week10-13 & Teaching Non-finite Verbs \\
\hline Week 2-3 & Teaching Imperatives & Week14-17 & Teaching Subjunctive Mood \\
\hline Week 4-6 & Teaching Passive Voice & Week 18 & post-test \\
\hline Week 7-9 & Teaching Attributives Clause & Week 18 & questionnaire \\
\hline
\end{tabular}

Table 3-2. The subjects' grammatical competence before the experiment

\begin{tabular}{|c|c|c|c|c|}
\hline \multicolumn{5}{|c|}{ Descriptive Statistics } \\
\hline Group & N & Mean & $\begin{array}{c}\text { Std. } \\
\text { Deviation }\end{array}$ & $\begin{array}{c}\text { T-test and Different } \\
\text { Analysis }\end{array}$ \\
\hline EC & 42 & 64.19 & 7.71 & \multirow{Z}{*}{$=0.083$} \\
\hline CC & 44 & 64.32 & 6.74 & \\
\hline
\end{tabular}

Table 3-3.The subjects' grammatical competence after the experiment

\begin{tabular}{|c|c|c|c|c|}
\hline \multicolumn{3}{|c|}{ Descriptive Statistics } \\
\hline Group & $\mathrm{N}$ & Mean & $\begin{array}{c}\text { Std. } \\
\text { Deviation }\end{array}$ & T-test and Different Analysis \\
\hline EC & 42 & 79.67 & 7.31 & $\mathrm{Z}=4.2$ \\
\hline CC & 44 & 71.14 & 11.23 & \\
\hline
\end{tabular}

Table 3-4.The subjects' grammatical competence before \& after the experiment (EC)

\begin{tabular}{|c|c|c|c|c|}
\hline \multicolumn{4}{|c|}{ Descriptive Statistics } \\
\hline EC & N & Mean & Std. Deviation & T-test and Different Analysis \\
\hline Pre-test & 42 & 64.19 & 7.71 & Z=9.44 \\
\hline Post-test & 42 & 79.67 & 7.31 & \\
\hline
\end{tabular}

Table 3-5.The subjects' grammatical competence before \& after the experiment (CC)

\begin{tabular}{|c|c|c|c|c|}
\hline \multicolumn{5}{|c|}{ Descriptive Statistics } \\
\hline CC & N & Mean & Std. Deviation & T-test and Different Analysis \\
\hline Pre-test & 44 & 64.32 & 6.74 & \multirow{Z}{*}{$\mathrm{Z}=3.46$} \\
\hline Post-test & 44 & 71.14 & 11.23 & \\
\hline
\end{tabular}


Table 3-6. Responses to the item 1

\begin{tabular}{|c|c|c|c|c|}
\hline \multirow{2}{*}{ Choices } & \multicolumn{2}{|c|}{ Experimental Class } & \multicolumn{2}{c|}{ Control class } \\
\cline { 2 - 5 } & Numbers & Percentage & Numbers & Percentage \\
\hline strongly agree & 18 & $42.9 \%$ & 16 & $36.3 \%$ \\
\hline agree & 21 & $50 \%$ & 20 & $45.4 \%$ \\
\hline disagree & 3 & $7.1 \%$ & 8 & $18.3 \%$ \\
\hline strongly disagree & 0 & -- & 0 & -- \\
\hline
\end{tabular}

Table 3-7. Responses to the item 2

\begin{tabular}{|c|c|c|c|c|}
\hline \multirow{2}{*}{ Choices } & \multicolumn{2}{|c|}{ Experimental Class } & \multicolumn{2}{c|}{ Control class } \\
\cline { 2 - 5 } & Numbers & Percentage & Numbers & Percentage \\
\hline strongly agree & 6 & $14.3 \%$ & 6 & $13.7 \%$ \\
\hline agree & 30 & $71.4 \%$ & 28 & $63.6 \%$ \\
\hline disagree & 6 & $14.3 \%$ & 10 & $22.7 \%$ \\
\hline strongly disagree & 0 & -- & 0 & -- \\
\hline
\end{tabular}

Table 3-8. Responses to the item 3

\begin{tabular}{|c|c|c|c|c|}
\hline \multirow{2}{*}{ Choices } & \multicolumn{2}{|c|}{ Experimental Class } & \multicolumn{2}{c|}{ Control class } \\
\cline { 2 - 5 } & Numbers & Percentage & Numbers & Percentage \\
\hline strongly agree & 8 & $19.1 \%$ & 10 & $22.7 \%$ \\
\hline agree & 25 & $59.5 \%$ & 20 & $45.4 \%$ \\
\hline disagree & 9 & $21.4 \%$ & 14 & $31.9 \%$ \\
\hline strongly disagree & 0 & -- & 0 & -- \\
\hline
\end{tabular}

Table 3-9. Responses to the item 4

\begin{tabular}{|c|c|c|c|c|}
\hline \multirow{2}{*}{ Choices } & \multicolumn{2}{|c|}{ Experimental Class } & \multicolumn{2}{c|}{ Control class } \\
\cline { 2 - 5 } & Numbers & Percentage & Numbers & Percentage \\
\hline strongly agree & 16 & $38.1 \%$ & 6 & $18.3 \%$ \\
\hline agree & 20 & $47.6 \%$ & 20 & $45.4 \%$ \\
\hline disagree & 6 & $14.3 \%$ & 18 & $36.3 \%$ \\
\hline strongly disagree & 0 & -- & 0 & -- \\
\hline
\end{tabular}

Table 3-10. Responses to the item 5

\begin{tabular}{|c|c|c|c|c|}
\hline \multirow{2}{*}{ Choices } & \multicolumn{2}{|c|}{ Experimental Class } & \multicolumn{2}{c|}{ Control class } \\
\cline { 2 - 5 } & Numbers & Percentage & Numbers & Percentage \\
\hline strongly agree & 9 & $21.4 \%$ & 9 & $20.4 \%$ \\
\hline agree & 28 & $66.7 \%$ & 18 & $40.9 \%$ \\
\hline disagree & 5 & $11.9 \%$ & 17 & $38.7 \%$ \\
\hline strongly disagree & 0 & -- & 0 & -- \\
\hline
\end{tabular}

